\title{
ARE THE FORESTS OF THE WIGRY NATIONAL PARK SUITABLE FOR THE COMMON DORMOUSE Muscardinus avellanarius?
}

\author{
1Department of Genetics and Animal Breeding, Warsaw University of Life Sciences - SGGW, \\ Poland \\ 2Wigry National Park, Krzywe, Poland
}

\begin{abstract}
The research was aimed at demonstrating whether the common dormouse Muscardinus avellanarius occurs in the area of the Wigry National Park. In order to detect the presence of this species, research areas in park stands were determined, characterized by a large share of hazel Coryllus avellana in the undergrowth. Hazel nuts gnawed by the species were sought on the 30 forest research plots. Nesting tubes, placed in May, and nest boxes for birds were checked till the first days of October. In addition, the summer nests of the species were searched. During the research, 6 nests of common dormouse were found and one individual of this species was observed. The results show that, despite the fact that the common dormouse is on the list of mammalian species found in the Wigry National Park, it rarely occurs there.
\end{abstract}

Key words: environmental monitoring, Wigry National Park, common dormouse, Muscardinus avellanarius.

\section{INTRODUCTION}

Wigry National Park is located in the northern part of the Augustów Primeval Forest. The total area of the park is $151 \mathrm{~km}^{2}$, of which forests cover more than 62\% (Adamczewska et al. 2009). Information on the presence of the common dormouse in the Augustów Primeval Forest is very scarce. About 20 years ago this species was observed in the Pomorze Forest District (Myszczyński, personal communication). On the official list of species of mammals of the Wigry National Park (WNP), the common dormouse is listed as a species occurring in the area. Unfortunately, there are no reliable source data to support this claim. This gives ground to question the list of the species of mammals living there. However, there is an oral report that about 15 years ago the species was observed in the southern part of the Park (Łapiński, personal communication). There are no other reports on the occurrence of the common dormouse in the park area.

As the forest environment of the Wigry National Park, with a large share of hazel in the undergrowth, theoretically may be the place of the occurrence of the species, it was decided to investigate whether it exists in the Park area at all.

Corresponding author: Wojciech Misiukiewicz, Wigry National Park, Krzywe 82, 16-402 Suwałki, Poland, e-mail: castor_f@poczta.wp.pl 


\section{MATERIAL AND METHODS}

There are 10 protection sites in the WNP. Within each, 3 main research areas were designated, i.e. a total of 30 areas throughout the Park.

In order to detect the presence of the common dormouse the gnawed hazel nuts (characteristically bitten by a dormouse) were searched. In order to detect the presence of the common dormouse 30 research areas of gnawing marks search were designated in the park. The forests of the Wigry National Park are characterized by a large share of hazel Corylus avellana and in such conditions this method could give good results (Bright et al. 2006). This method was employed in September. According to the method of Bright et al. (1994, 2006), half-hectare areas were designated in which five $5 \times 5 \mathrm{~m}$ areas were randomly selected. These areas were searched for 20 minutes. It was assumed that if gnawing marks were not found after searching five areas, the presence of dormice in a given area was to be excluded.

The nesting tubes, designed for dormice, were placed throughout the Park. These light constructions of a cuboid shape with a sliding wooden floor are used to detect common dormouse (Bright et al. 2006; Czapracka et al. 2010). Both original nesting tubes made of polypropylene (Fig. 1A) and constructions of impregnated cardboard prepared ourselves (Fig. 1B), were used.

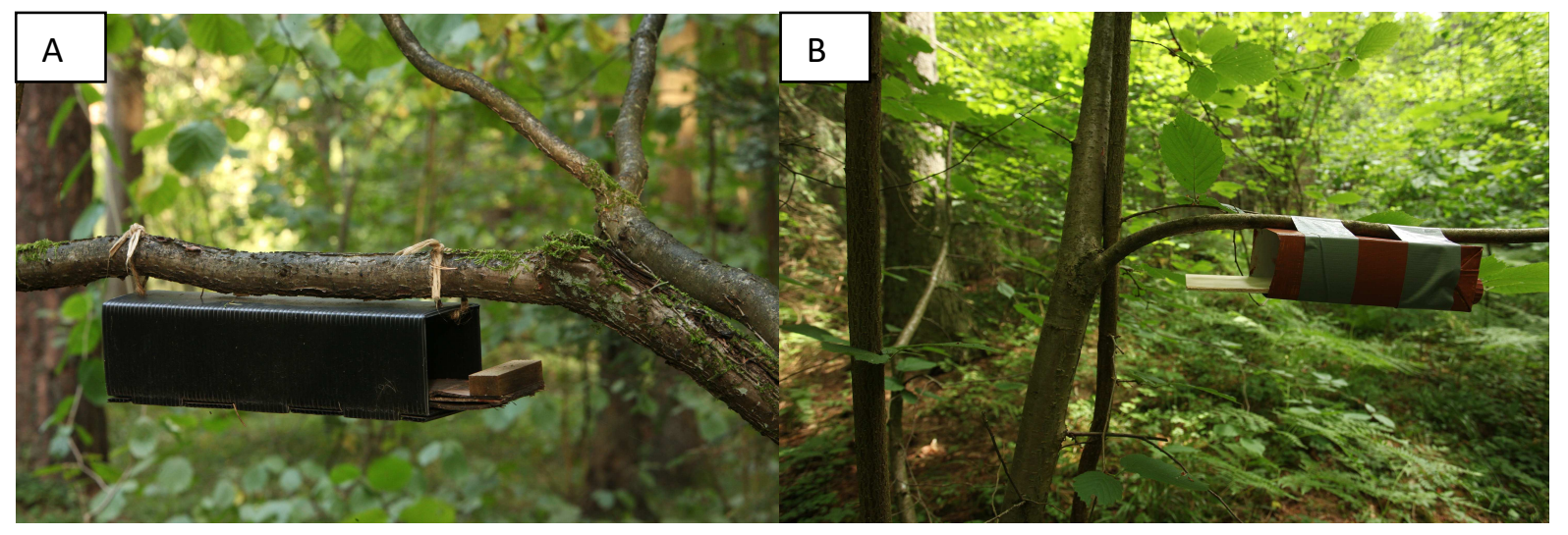

Fig. 1. Types of nesting tubes used to detect the presence of common dormice (photo W. Misiukiewicz)

In each protection site two areas with nesting tubes were designated. In each research area 40 tubes were placed, i.e. the total number of nesting tubes placed in the Park was 800 and this gave 20 research areas in the entire Park, where a total of 800 nesting tubes were placed. Areas with an extremely high share of hazel were selected as research areas. Tubes were hung at a height of 0.5 to $1.8 \mathrm{~m}$ above the ground. Tubes were controlled every 2 weeks from May to the first days of October.

The common dormouse is a species that eagerly inhabits nesting boxes for birds (Jurczyszyn et al. 2016). In the summer, they can take up to $40 \%$ of the boxes (Ważna et al. 2012). Therefore, additional control of bird nest boxes was carried out (Fig. 2). Type A and 
A1 boxes are hung in all protection sites in the Park. The search for nests in nesting boxes is - apart from searching for gnawing marks on hazelnuts - one of the most effective methods to detect the presence of the species (Jurczyszyn 2004).

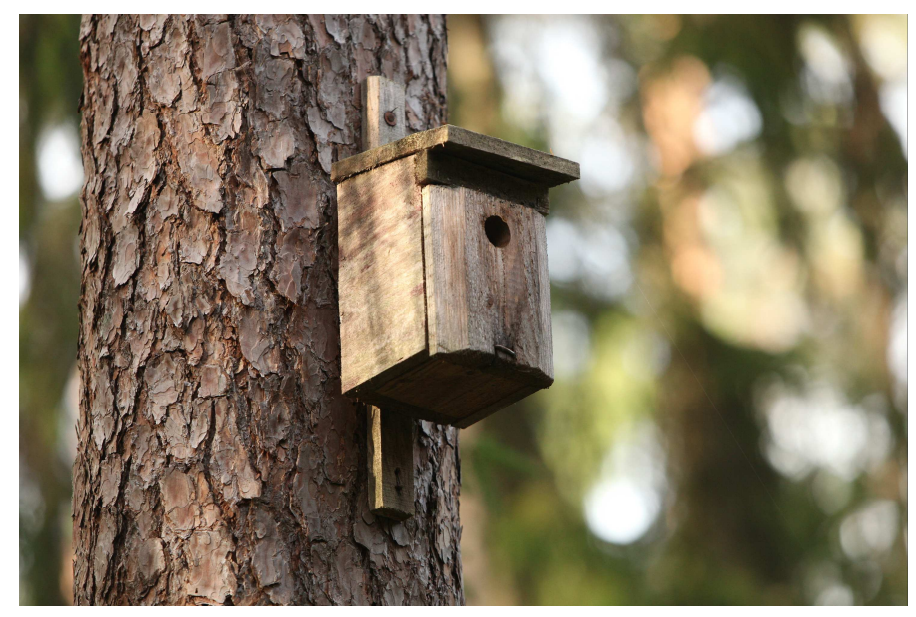

Fig. 2. One of the nesting boxes in which the nests of common dormice were sought (photo W. Misiukiewicz)

Inspections were aimed at searching for dormice nests, as it is known that these animals willingly use bird nesting boxes for their own purposes. In total, 510 nesting boxes were inspected. In individual protection sites (O.O.) numbers were as follows:

- O.O. Krzywe - 30 pcs.

- O.O. Leszczewek - 20 pcs.

- O.O. Lipniak - 30 pcs.

- O.O. Gawarzec - 60 pcs.

- O.O. Słupie - 100 pcs.

- O.O. Powały - 60 pcs.

- O.O. Krusznik - 40 pcs.

- O.O. Mikołajewo - 50 pcs.

- O.O. Wysoki Most - 70 pcs.

- O.O. Lipowe -50 pcs.

\section{RESULTS}

\section{Searching for gnawed hazel nuts}

Due to the exceptional drought that occurred in the vegetation season in 2018, there was a crop failure of the common hazel. No nuts were found that could have been damaged by common dormice. Therefore, our research did not show the presence of this species in the area.

\section{Nesting tube controls}

During inspections, the presence of dormice was found in the Powały protection site, in the $383 \mathrm{~h}$ section (Fig. 3A). Tree nested tubes were found and one animal was observed. Two nests had a single layer structure made of leaves. The third one was two layered with 
distinct outer (leaves) and inner (grass) layers. All nested tubes were placed at height from 0.8 to $1.3 \mathrm{~m}$ above the ground, which is typical for this species (Vilhelmsen 1996; Juškaitis and Remeisis 2007; Čanády 2015). The forest type in the research area is a fresh mixed one.

Additionally, in the Lipowe protection site (O.O.) (Fig. 3B), two nests in tubes made of tubular polypropylene have been found. The inner layer of the two layer nest consisted of grasses, small fragments of hazel and birch leaves, single tree pins. Tubes in which nests were found were located at a height of about $1 \mathrm{~m}$ from the ground. The forest type in the research area where nesting tubes were placed was a mixed fresh forest.

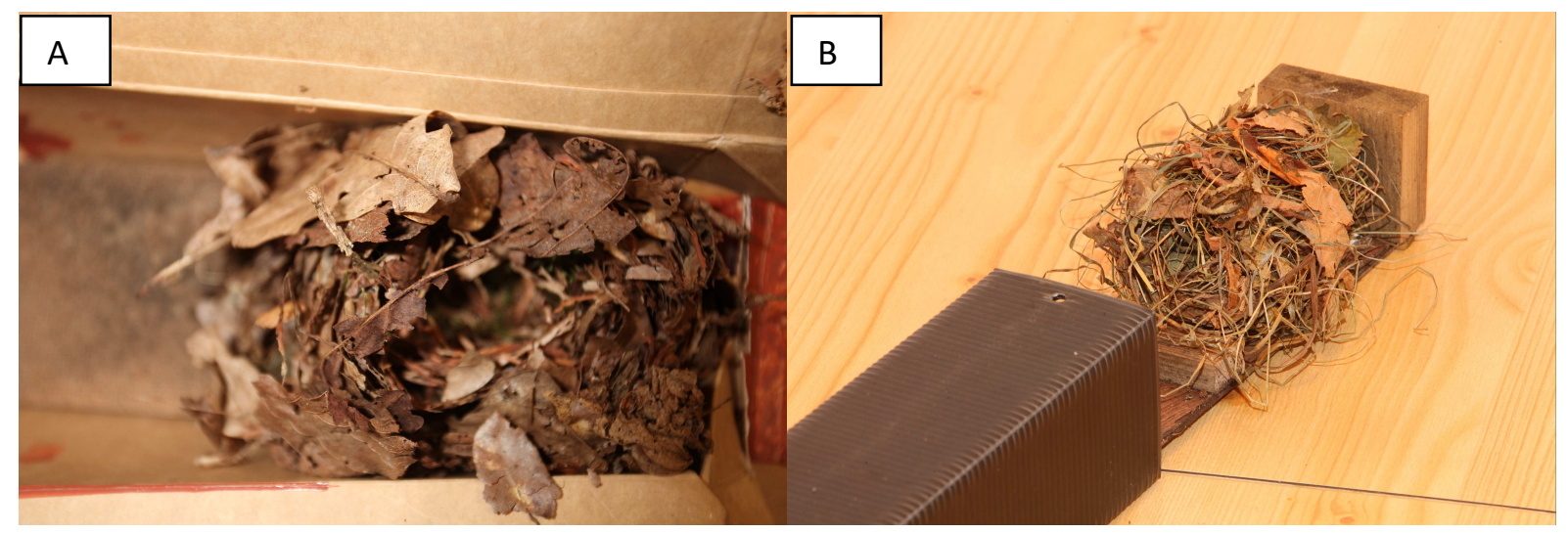

Fig. 3. Nest of a common dormouse in a cardboard nesting tube $(A)$ and a polypropylene nesting tube (B) (photo W. Misiukiewicz)

\section{Checking of nest boxes for birds}

The inspection of nesting boxes was carried out on September 26.09-5.10. 2018 and one summer nest of a common dormouse in O.O. Krzywe was found. It was a summer single layer nest made of leaves, built on a nest of moss left in the nesting box by birds. This location was characterized by a large share of hazel in the undergrowth.

\section{DISCUSSION}

To detect the presence of the common dormouse in the Wigry National Park 800 nesting tubes and 510 nest boxes for birds were inspected, and teeth marks on hazelnuts in 30 study plots were checked. A small number of findings (6 nests and 1 direct observation of the species) indicate that the common dormouse is not a common mammal species inhabiting the National Park. An interview among the field services of forest inspectorates from the area of the Augustów Primeval Forest showed that this species has not been observed in the area. The only exception was a single historical (from about 20 years ago) observation in the Pomorze Forest District (Myszczyński, personal communication).

Common dormouse feeds mainly on seeds and fruits of the trees, and periodically also eats insects and their larvae (Kowalski and Pucek 1984). In order to show the presence of this species in the lowland areas of Poland, the method of finding traces of foraging on hazel nuts (Czapracka et al. 2010) successfully applies. The share of hazel in the shrub of the Wigry National Park is very high. This is due to the fact that in the years 1994-1996, in order 
to protect the stability of the forest, it was decided to perform considerable cuts in the stands. It was related to the bark beetle Ips typographus gradation. Although timber harvesting resulted from the current sanitary needs of tree stands, these activities lead to the unveiling of large forest areas (Operat ochrony ekosystemów... 2014). This made the hazel find excellent conditions for growth and expansion and it is now the basic shrub species in the Wigry National Park. Due to the drought that occurred in the 2018 season, which resulted in small crop of hazelnuts, finding hazelnuts gnawed by common dormouse was ineffective. During the research, not a single locality of common dormouse was detected by this method.

As mentioned earlier, the area is characterized by a large share of hazel in the undergrowth. Nevertheless, the undergrowth lacks species of plants that can provide cover and places to build summer nests. The share of raspberries is low; there are no blackberries and other shrubs in which animals could build their nests. This may be one of the reasons that the population density is low.

The common dormouse is a hibernating species and therefore has short period of its activity from May to October. Because the area of the Suwałki region is characterized by the low average annual temperatures and shortened vegetation period, it is possible that these factors also limit the presence of the species in the area of the Augustów Primeval Forest.

During the research we searched for nests. Dormice prefer hiding in trunk hollows to nesting among vegetation (Bright and Morris 1989, 1992; Berg and Berg 1998; Morris 2004). Nesting boxes for birds in their structure are similar to natural hollows, which is why animals choose them as a safe shelter (Morris et al. 1990; Juškaitis 2005) and a place used for breeding and rearing young (Jurczyszyn et al. 2016).

In addition, the dispersion of the species is small. The individual area of these dormice is about 1 ha. Young animals usually move away from the place of birth at 130-360 m, and the longest documented migrations did not exceed $1200 \mathrm{~m}$. In the first year of life, most young animals lead sedentary lives (Juškaitis 1997). The control of nest boxes confirmed the presence of common dormice in protection site Krzywe, which is characterized by a large share of hazel in the shrub. Materials of natural origin were used for the construction of nest leaves of trees and shrubs. The leaves were dry. When constructing their nests, dormice usually use leaves from branches adjacent to the nest (Airapetjanc 1983), and that was also in the Park where animals used leaves from nearby woody plants as building material. Also plant leaves growing nearby were used for construction (Bracewell 2009). In total, common dormice used hazelnut, oak, linden and birch leaves in nest constructions. As the dominant species in the area was hazel, it was the largest building stock (Wachtendorf 1951; Lozan 1970; Zaytseva 2006).

Although no summer nests have been found in bird nesting boxes, placed in other protection sites in the Park, this does not mean that the species does not occur there. Nest boxes are placed randomly in old trees, mostly outside the areas of the occurence of hazel shrub. The biggest number of nests was detected in nesting tubes placed in research fields in O.O. Powały, where 3 nests were found and a single specimen was seen. Observations from the Roztocze National Park proved that small nests built by dormice in so-called nesting tubes (small sized constructions, made of cardboard or polypropylene and plywood), serving as artificial shelters for dormice, can also be used as shelters for females with their young (Jurczyszyn et al. 2016). 
According to information from the local resident, Rafał Łapiński, about 15 years ago a specimen was caught there. The presence of the species is documented in photographs. There are no other reports on the occurrence of common dormouse in the Park area. O.O. Powały is characterized by the highest share of hazel in the shrub. In addition, near the study plot where nesting tubes were placed, stand plantation partly covered with raspberry bushes was found. Another 2 nests were found in polypropylene tubes in the O.O Lipowe. This area was also characterized by a large proportion of hazel in the undergrowth, though generally the share of hazel is lower there than in O.O. Powały.

\section{CONCLUSIONS}

Common dormouse Muscardinus avellanarius is the only representative of dormice (Gliridae) occurring in the Wigry National Park. However, small number of findings indicates that it is not a common one. In total, 6 nests of this species were found and 1 individual was observed. Although the area of the Park is characterized by a large share of hazel in the undergrowth, it lacks the species (e.g. blackberry, raspberry) that can provide cover and places to build summer nests. This may be one of the factors, limiting the development of the population. In addition, the area of the Suwałki region, compared to other regions of the country, is characterized by the lowest average annual temperatures and shortened vegetation period. Because the common dormouse is a hibernating species, it cannot be ruled out that these factors also limit its presence in the area of the Wigry National Park and the entire Augustów Primeval Forest.

\section{REFERENCES}

Airapetjanc A.E. 1983. Žyzn' našych zverej i ptic. Leningrad, Izdatelstvo LGU. [in Russian]

Adamczewska J., Adamczewski J., Ambrosiewicz M., Borejszo J., Górecka J., Kamiński M., Krzysztofiak A., Krzysztofiak L., Łoziński J., Misiukiewicz W., Osewski M. Pieczyński P., Romański M., Stankiewicz M. 2009. Lasy nad Wigrami. Krzywe, Wigierski Park Narodowy, 43. [in Polish]

Berg L., Berg A. 1998. Nest site selection by the dormouse Muscardinus avellanarius in two different landscapes. Ann. Zool. Fenn. 35, 115-122.

Bracewell M. 2009. Nest material preferences in the common dormouse, Muscardinus avellanarius, in the Southern United Kingdom. MSc. Habitat Creation and Management. Staffordshire University.

Bright P.W., Morris P.A. 1989. A practical guide to dormouse conservation. London, The Mammal Society.

Bright P.W., Mitchell P., Morris P.A. 1994. Dormouse distribution: survey techniques, insular ecology and selection of sites for conservation. J. Appl. Ecol. 31, 329-339.

Bright P.W., Morris P.A. 1992. Ranging and nesting behaviour of the dormouse Muscardinus avellanarius, in coppice-with-standard woodland. J. Zool. 226, 589-600.

Bright P.W., Morris P.A., Mitchell P. 2006. The dormouse conservation handbook, 2nd ed. Peterborough, English Nature. ISBN 1857162196.

Canady A. 2015. Factors predicting summer nest construction of Muscardinus avellanarius in deciduous woodland edges in Slovakia. Biologia 70, 132-140.

Czapracka A., Jurczyszyn M., Zawadzka M. 2010. Studia nad orzesznicą Muscardinus avellanarius w Parku Krajobrazowym Promno (Wielkopolska) [Study on the common dormouse Muscardinus avellanarius in Promno Landscape Park (Greater Poland)]. Chrońmy Przyr. Ojcz. 66(5), 353-360. [in Polish] 
Jurczyszyn M. 2004. Ochrona ssaków nadrzewnych, w: Ochrona przyrody w lasach. Cz. I. Ochrona zwierząt. Red. D.J. Gwiazdowicz. Poznań, Wydaw. Pol. Tow. Leś., 121-132. [in Polish]

Jurczyszyn M., Karminska L., Czapracka A., Marchewka A. 2016. Letnie gniazda orzesznicy Muscardinus avellanarius w Parku Krajobrazowym Promno [Summer nests of common dormouse Muscardinus avellanarius in Promno Landscape Park]. Chrońmy Przyr. Ojcz. 72(3), 196-205. [in Polish]

Juškaitis R. 1997. Ranging and movement of the Common dormouse Muscardinus avellanarius in Lithuania. Acta Theriol. 42 (2), 113-122.

Juškaitis R. 2005. The influence of high nestbox density on the common dormouse Muscardinus avellanarius population. Acta Theriol. 50, 43-50.

Juškaitis R., Remeisis R. 2007. Summer nest sites of the common dormouse Muscardinus avellanarius in young woodlands of Lithuania. Pol. J. Ecol. 55(4), 795-803.

Kowalski K., Pucek Z. 1984. Rodzina: Popielicowate (pilchowate) - Gliridae, w: Klucz do oznaczania ssaków Polski. Red. Z. Pucek. Warszawa, PWN, 224-237. [in Polish]

Lozan M.H. 1970. Gryzuny Moldavii. Kišiniev, Redakcjonno-izdatielski otdel Akademii Nauk Moldavskoj SSR. [in Russian]

Morris P. 2004. Dormice. Suffolk, Whittet Books Ltd.

Morris P.A., Bright P.W., Woods D. 1990. Use of nestboxes by the dormouse Muscardinus avellanarius. Biol. Conser. 51, 1-13.

Operat ochrony ekosystemów leśnych. Plan ochrony dla Wigierskiego Parku Narodowego i Obszaru Natura 2000 Ostoja Wigierska PLH 200004. 2014. Red. M. Szneidrowski. Warszawa, Narodowa Fundacja Ochrony Środowiska. [in Polish]

Vilhelmsen H. 1996. The distribution, habitat requirements and nestsites of the common dormouse in Denmark, in: Schläfer und Bilche. Tagungsbericht 1. Intern. Bilchkolloquium, St. Oswald 1990, Ed. H. Müller-Stiess. Neuschönau, Verein der Freunde des Ersten Deutschen Nationalparks Bayerischer Wald e. V., 49-55.

Wachtendorf W. 1951. Beiträge zur Ökologie und Biologie der Haselmaus (Muscardinus avellanarius) im Alpenvorland. Die Zoologischen Jahrbücher 80, 189-204. [in German]

Ważna A., Cichocki J., Mierczak Z., Zwijacz-Kozica T., Owca M. 2012. Występowanie i rozmieszczenie orzesznicy Muscardinus avellanarius w polskiej części Tatr i na Podtatrzu [The occurence and distribution of the common dormouse Muscardinus avellanarius in the Polish part of Tatra Mountains and the Sub Tatra Montain]. Chrońmy Przyr. Ojcz. 68(2), 91-99. [in Polish]

Zaytseva H. 2006. Nest material of the common dormouse (Muscarinus avellanarius L.) used in nestboxes, Podilla (West Ukraine). Pol. J. Ecol. 54, 397-401.

\section{CZY LASY WIGIERSKIEGO PARKU NARODOWEGO SPRZYJAJA WYSTĘPOWANIU ORZESZNICY LESZCZYNOWEJ Muscardinus avellanarius?}

Streszczenie. Badania miały na celu wykazanie, czy orzesznica leszczynowa (Muscardinus avellanarius) występuje na obszarze Wigierskiego Parku Narodowego. W celu wykrycia obecności tego gatunku wyznaczono powierzchnie badawcze w drzewostanach parku, charakteryzujących się dużym udziałem leszczyny (Coryllus avellana) w podszycie. Obserwacje terenowe prowadzono na 30 powierzchniach, na których poszukiwano pogryzów na orzechach laskowych. Ponadto w maju rozwieszono tuby gniazdowe, w których do pierwszych dni października poszukiwano gniazd letnich gatunku; jesienią skontrolowano budki lęgowe dla ptaków. Podczas prowadzenia 
badań odnaleziono 6 gniazd orzesznicy leszczynowej oraz zaobserwowano osobnika tego gatunku. Wyniki wykazały, że orzesznica leszczynowa jest to gatunek, który nielicznie występuje na obszarze Parku i wchodzi w skład gatunkowy teriofauny.

Słowa kluczowe: inwentaryzacja przyrodnicza, Wigierski Park Narodowy, orzesznica leszczynowa, Muscardinus avellanarius.

The research was financed from a forestry fund as part of a research project financed by the General Directorate of State Forests in Warsaw. 